\title{
Generat broni Lucjan ŻELIGowski (1865-1947) Przyczynek do biografii
}

Słow a klu cz ow e: biografia, wojna rosyjsko-japońska, generalicja Wojska Polskiego, zamach stanu w 1926 roku, wojny światowe, słowianofilstwo

Keywords: biography, Russian-Japanese War, generals of the Polish Army, coup d'état in 1926, World Wars, Slavophilism

\section{SUMMARY}

General Lucjan Żeligowski came from a Polish noble family, the coat of arms "Bończa". His ancestors fought against the Swedes in the sixteenth century and his father participated in the January Uprising in 1863. He is one of the most controversial figures in the corps of generals of the Second Polish Republic. He fought in the Russian-Japanese War (1904-1905). During the Great War, after the consent of the Russian authorities to create Polish military formations, he was a co-organizer of the Polish Riflemen Brigade, he fought in the ranks of the Polish Rifle Division and the Polish First Corps. In the final period of the war he co-organized the 4th Polish Rifle Division, with which he reached Poland via Odessa and Bessarabia. He fought with the armies of the Western Ukrainian People's Republic and in the Polish-Soviet War - the Northern Front (10 DP) and in the fighting at Radzymin (during the Battle of Warsaw). After the war, the 1. Lithuanian-Belorussian Infantry Division took Vilnius and led to the creation the Republic of Central Lithuania. „Z̈eligowski's Mutiny” resulted in joining this area to Poland. In the Polish Army he was the commander of 
the Army Inspectorate No. 2 in Warsaw and the Minister of Military Affairs. After Piłsudski's coup d'état (the May coup), he stood at the head of the Liquidation Commission set up to clarify the circumstances and course of May events in 1926. He was also an Inspector of the Army in the General Inspectorate of the Armed Forces. On August 31, 1927, he retired. In 1928 he became the president of the Chapter of the Order of Polonia Restituta and a member of the State Tribunal. In 1935 he was elected a member of the Parlament (Sejm) of the 4th term from the list of the Non-Partisan Block of Cooperation with the Government - he chaired the Parlament Military Commission, and then the Parlament (Sejm) of the 5th term from the non-party list. During World War II, he was a member of the National Council of the Republic of Poland, chairman of its Military Committee and Chancellor of the Order of Virtuti Militari. A supporter of Slavophile in the postwar period, he was in favor of cooperation with the USSR. He died in London in 1947. He rests at the Military Cemetery in Powązki in Warsaw.

\section{STRESZCZENIE}

Generał Lucjan Żeligowski pochodził z polskiej rodziny szlacheckiej, herbu „Bończa”. Jego przodkowie walczyli ze Szwedami w XVI wieku, a jego ojciec brał udział w powstaniu styczniowym w 1863 roku. Jedna z najbardziej kontrowersyjnych postaci w korpusie generałów II RP. Walczył w wojnie rosyjsko-japońskiej (1904-1905). Podczas Wielkiej Wojny, po zgodzie władz rosyjskich na tworzenie polskich formacji wojskowych, był współorganizatorem Brygady Strzelców Polskich, walczył w szeregach Polskiej Dywizji Strzelców i w Pierwszym Korpusie Polskim W ostatnim okresie wojny współorganizował 4. Dywizję Strzelców Polskich, z którą dotarł do Polski przez Odessę i Besarabię. Walczył z wojskami Zachodnioukraińskiej Republiki Ludowej i w wojnie polsko-radzieckiej - na Froncie Północnym (10 DP) oraz w walkach pod Radzyminem (podczas bitwy warszawskiej). Po wojnie na czele 1. Dywizji Piechoty Litewsko-Białoruskiej zajął Wilno i doprowadził do powstania Republiki Litwy Środkowej. „Bunt Żeligowskiego” zaowocował przyłączeniem tego obszaru do Polski. W Wojsku Polskim był dowódcą Inspektoratu Wojskowego nr 2 w Warszawie i Ministrem Spraw Wojskowych. Po zamachu stanu Piłsudskiego (zamachu majowym) stanął na czele Komisji Likwidacyjnej powołanej w celu wyjaśnienia okoliczności i przebiegu wydarzeń majowych w 1926 r. Był także inspektorem armii w Generalnym Inspektoracie Zbrojnym Siły. 31 sierpnia 1927 r. przeszedł na emeryturę. W 1928 r. został przewodniczącym Kapituły Orderu Odrodzenia Polski i członkiem Trybunału Stanu. W 1935 r. został wybrany posłem na Sejmu IV kadencji z listy Bezpartyjnego Bloku Współpracy z Rządem - przewodniczył Komisji Wojskowej Parlamentu, a następnie był posłem na Sejm V kadencji z listy bezpartyjnej. Podczas II wojny światowej był członkiem Rady Narodowej Rzeczypospolitej Polskiej, przewodniczącym Komitetu Wojskowego i kanclerzem Orderu Virtuti Militari. Zwolennik słowiano- 
filstwa. W okresie powojennym opowiadał się za współpracą z ZSRR. Zmarł w Londynie w 1947 r. Spoczywa na Cmentarzu Wojskowym na Powązkach w Warszawie.

Za służbę Ojczyźnie nikt nie potrzebuje cudzego podziękowania. gen. Lucjan Żeligowski

Drzez rzez ostatnie trzy dekady po zmianie systemu politycznego w Polsce środowisko historyków podjęło szerokie badania nad dziejami Drugiej Rzeczypospolitej. Jednym z ważniejszych obszarów analiz jest problematyka studiów nad dziejami Wojska Polskiego, a szczególnie losami żołnierzy i ich dowódców, którzy wpływali nie tylko na charakter działań militarnych (walki o granice Rzeczypospolitej po I wojnie światowej czy wojna obronna Polski w 1939 r.) oraz na kierunku rozbudowy armii, ale również uczestniczyli w życiu politycznym państwa. Problematyka badań nad generalicją Wojska Polskiego posiada bogate zaplecze w postaci licznych słowników biograficznych i zapisów encyklopedycznych ${ }^{1}$.

Ważnym źródłem dla studiów nad biografistyką wojskową, są zespoły archiwalne znajdujące się w Centralnym Archiwum Wojskowym w Warszawie, np. teczki osobowe (akta personalne) znajdujące się w Kolekcji generałów i wyższych osobistości, a także: „Roczniki Oficerskie” z 1923 i 1924 r., 1928 r. 1932 r. i „Dzienniki Personalne MSWojsk.”oraz zestawienia w formie roczników oficerskich opracowane przez Ryszarda Rybkę i Kamila Stepana².

1 W grupie słowników biograficznych i opracowań na uwagę zasługują prace: T. Kryska-Karski, S. Żurakowski, Generałowie Polski Niepodległej, Londyn 1976; wyd. II (uzupełnione i poprawione), Warszawa 1991; P. Stawecki, Słownik biograficzny generałów Wojska Polskiego 1918-1939, Warszawa 1994. Idem, Generałowie polscy. Zarys portretu zbiorowego 1776-1945, Warszawa 2010, s. 99-237; Z. Machaliński, Admirałowie polscy 1919-1950, Warszawa 1993; M. Bielski, Generałowie Odrodzonej Rzeczypospolitej, t. 1-2, Torun 1995, 1998; Kadry morskie Rzeczypospolitej, t. 2: Polska Marynarka Wojenna, cz. I: Korpus oficerów 1918-1947, pod red. J.K. Stawickiego, Gdynia 1996; H.P. Kosk, Generalicja polska. Popularny słownik biograficzny, t. 1-2, Pruszków 1998, 2001; S. Czuma, W. Wójcik, Generałowie w stalowych mundurach, Warszawa 2003; A. Wojtaszak, Generalicja Wojska Polskiego 1918-1926, Szczecin-Warszawa 2012 oraz idem, Generalicja Wojska Polskiego 1935-1939. (Analiza grupy funkcjonalno-decyzyjnej), Szczecin 2018.

2 R. Rybka, Kamil Stefan: Awanse oficerskie w Wojsku Polskim w latach 1935-1939, Kraków 2003, oraz Rocznik oficerski 1939 : stan na dzień 23 marca 1939, Kraków 2006. 
Prezentowany artykuł jest rezultatem prowadzonych przez autora badań, których celem jest przedstawienie losów generałów Wojska Polskiego (WP) okresu II Rzeczypospolitej. Wśród 21 wyższych oficerów WP minowanych na stopień generała broni, czternastu nominacje uzyskało przed 1 września 1939 r. W grupie tej znajdowali się: Leon Berbecki, Józef Dowbór-Muśnicki, Karol Durski-Trzaska, Józef Haller, Wacław Iwaszkiewicz-Rudoszański, Kazimierz Raszewski, Tadeusz Rozwadowski, Kazimierz Sosnkowski, Stanisław Szeptycki, Edward Śmigły-Rydz (Marszałek Polski), Zygmunt Zieliński, Lucjan Żeligowski oraz dwaj tytularni generałowie broni Kajetan Olszewski, Jan Rządkowski. W okresie II wojny światowej mianowano Władysława Sikorskiego, a po wojnie Władysława Andersa, Michała Tokarzewskiego-Karaszewicza i Stanisława Maczka. Do wspomnianej grupy należą również mianowani pośmiertnie, pomordowani na wchodzie w Katyniu i Charkowie w 1940 r. Stanisław Haller, Henryk Minkiewicz - Odrowąż oraz Leonard Skierski ${ }^{3}$

Przedmiotem prezentowanej w tym artykule analizy są losy generała broni Lucjana Żeligowskiego. Na ten temat powstało już wiele opracowań i not biograficznych ${ }^{4}$.

3 Postanowienie Prezydenta Rzeczypospolitej Polskiej z dnia 5 października 2007 r., nr 112-48-07 o nadaniu stopni generalskich, „Monitor Polski”, 2007, nr 85, poz.885.

${ }^{4} \mathrm{Na}$ temat losów gen. broni Lucjana Żeligowskiego ukazało się kilka opracowań naukowych i popularyzatorskich. O generale pisali: W. Marczyk, Generał broni Lucjan Żeligowski, „Wojskowy Przegląd Historyczny” 1987, nr 4; W. Kicman, Jeszcze w sprawie gen. broni L. Żeligowskiego, «Wojskowy Przegląd Historyczny», 1988, nr 2. Biografię generała napisała B. Gumowska, Opowieść o gen. broni Lucjanie Żeligowskim, Bydgoszcz 1994, cz. 1. Lata 1865-1920 oraz Dariusz Fabisz. Por. D. Fabisz, Generał Lucjan Żeligowski 1865-1947. działalność wojskowa i polityczna, Warszawa 2007. Autor ten pisał także o udziale generała w walkach o niepodległość Polski, idem, Generał Lucjan Żeligowski w walce o Polskę i jej granice w latach 1914-1921, [w:] Listopad 1918 z perspektywy osiemdziesięciolecia, red. Cz. Osękowski, Zielona Góra 2000, s.113-120 oraz K. Galas, Generał broni Lucjan Żeligowski i jego zasługi dla niepodległości Rzeczypospolitej Polskiej, „Niepodległość i Pamięć», 2009 nr 29, s. 197-204.

Powstało również kilka not biograficznych generał. Por. T. Kryska-Karski, S. Żurakowski, Generałowie Polski Niepodległej, Warszawa 1991, s. 21; B. Polak (red.), Kawalerowie Virituti militari 1792-1945, t. II (1914-1921), cz. 2, s.243; H.P. Kosk, Generalicja polska. Popularny słownik biograficzny, Pruszków 2001, t. II, s.292; W. Ruszkowski, J. Kofman (red.), Słownik biograficzny Europy Środkowo-Wschodniej XX w., Warszawa 2004, s. 1441; P. Stawecki, Słownik biograficzny generałów Wojska Polskiego 1918-1938, Warszawa 1994, s. 373; A. Suchcitz, Generałowie wojny polsko-sowieckiej 1919-1920, Białystok 
Lucjan Mieczysław Rafał Żeligowski ${ }^{5}$ urodził się 19 września/2 października 1865 r. ${ }^{6}$, folwark Przechody (Pierechody), w pobliżu Soły. Był synem Gustawa, szlachcica (herbu Belina) ${ }^{7}$, powstańca z 1863 r. oraz Władysławy Tarczewskiej. Oboje rodzice zostali zesłani w głąb Rosji, skąd nie wrócili ${ }^{8}$. Sakrament chrztu otrzymał w parafii rzymsko-katolickiej w Sołach w dniu 5 października 1865 r. , chrzestnmi byli - kapitan 2. Sofijskiego Pułku Piechoty

1992, s.89, oraz biogram sporządzony przez autora opracowania. Por. A. Wojtaszak, Generalicja Wojska Polskiego 1918-1926, Warszawa 2012, s.792-793. Na uwagę zasługuje także praca Henryka Bagińskiego, Wojsko Polskie na Wschodzie 1914-1920, Warszawa 1921 oraz biogramy internetowe, [w:] Russkaâ armiâ v Velikoj vojne, (Русская армия в Великой войне, [w:] http://www.grwar.ru/ persons/persons.html?id=1817, data dostępu: 2.06.2019).

${ }^{5}$ Informacje na temat losów gen. broni Lucjania Żeligowskiego możemy znaleźć w wielu archiwach w Polsce i poza granicami naszego kraju. Liczne źródła znajdują się w zbiorach Archiwum Akt Nowych w Warszawie (AAN), Zespoł gen. Lucjana Żeligowskiego 1889-1939, 1944-1947; w Centralnym Archiwum Wojskowym w Warszawie, Kolekcja generałów i wielkich osobistości. Akta gen. Lucjana Żeligowskiego, mf. sygn. I.480. 295.

Na uwagę zasługują również informacje znajdujące się w wydawanych przez Ministerstwo Spraw Wojskowych „Dziennikach Personalnych” ( Dz. P.) z 15.05. 1920, nr 18, pkt. 504; 6.10.1920, nr 38, pkt. 887; 29.10.1921, nr 39, pkt., 1831; 25.02.1922, nr 3, s. 141; 30.04.1922, nr 19, s. 322; 1.11.1922, nr 43, s. 823, 18.01.1923, nr 4, s.22; 02.04.1924, nr 32, s.165; 01.12.1925, nr 129, s.697,8.05.1926, nr 20, 151, 14.10.1926, nr 44, s. 354. Ważne dane możemy znaleść także w polskich i rosyjskich spisach i rocznikach oficerskich, por. Spisok kapitanam armejskoj pehoty po staršinstvu. Sostavlen na 01.11.1913, St. Petersburg 1914; Spisok polkovnikam po staršinstvu. Sostavlen po 01.08.1916, Piotrogród 1916, s. 335; oraz „Rocznikach Oficerskich” z 1923, s. 119; 1924, s. 116.

${ }^{6}$ Kalendarz gregoriański (nowy styl) w latach 1800-1899 wyprzedzał juliański (stary) o 12 dni a od 1900 r. o 13 dni.

${ }^{7}$ O przodkach generała Żeligowskiego pisano już XVI stuleciu. Bartosz Paprocki w Herbach rycerstwa polskiego, zapiał: „Dom Żeligowskich w łęczyckim województwie starodawny, z których Jakób będąc w wieku mego rotmistrzem, naprzód w Smeltynie, potem w Nowogrodku, od początku wojny inflandzkiej, w znacznych potrzebach wielkie swe męstwo okazywał. Pod Londem zamkiem, gdy Szwedom była armata pobrana (sic!), pod Rewlem pod sprawą Talbosa, kasztelana żmudzińskiego bywał i nieźle sobie poczynał, pod Semeltynem i pod Hadzhłem zamki, także i pod Kiesia, i w innych potrzebach $\mathrm{w}$ onych krajach $\mathrm{z}$ wielkim niebezpieczeństwem zdrowia swego, więźnie znacznie wodził i wiele ręką swoją nieprzyjaciół pobił, mąż pamięci godny". Herby rycerstwa polskiego. Przez Bartosza Paprockiego zebrane i wydane w r. p. 1584, Kraków 1858, s.430.

${ }^{8}$ Dariusz Fabisz uważa, że rodzice Żeligowskiego ( co było tajemnicą) pozostali na Litwie, gdzie się ukrywali. Por. D. Fabisz, Generał Lucjan Żeligowski 1865-1947...,s. 24. 
- Lucjan Mikosza i wdowa Pelagia Zdanowska. ${ }^{9}$. Lucjan Żeligowski był wychowywany w domu dalekich krewnych ze strony matki Waleriana i Erny ( $\mathrm{z}$ domu Tornau) Mikoszów a następnie przez ciotkę Katarzynę Mikosz. Pierwsze nauki pobierał w szkole gminnej w Żupranach a następnie w gimnazjum klasycznego (siedmioklasowe) w Wilnie. Maturę uzyskał jako ekstern, zdając egzaminy maturalne w gimnazjum na Antokolu w Wilnie.

Po zdaniu matury Lucjan Żeligowski wstąpił do wojska, jako jednoroczny ochotnik i dostał przydział do 115 . Wiaziemskiego Pułku Piechoty ${ }^{10}$, skąd został skierowany (za dobrą służbę) do szkoły junkrów. W 1885 r. rozpoczął edukację wojskową w Wileńskiej Szkole Junkrów Piechoty w Rydze ( podporucznik - 1 września 1887 r.). Po jej ukończeniu w 1888 r. rozpoczął służbę

${ }_{9}$ Data urodzi Żeligowskiego budzi wiele kontrowersji i wątpliwości. W AAN we wstępie do Zespołu gen. Lucjana Żeligowskiego 1889-1939, 1944-1947, podano datę 2 października $1865 \mathrm{r}$. W dokumentach carskich widnieje data 19 września $1865 \mathrm{r}$. Biorąc pod uwagę różnicę pomiędzy kalendarzem juliańskim i gregoriańskim daty te pokrywają się. $Z$ kolei sam gen. Żeligowski w wypełnianym pod koniec życia kwestionariuszu osobowym podał datę 19 października 1865 r. a jako miejsce urodzenia Nieśwież. Równie problematycznym wydają się być określenie miejsca urodzenia obok wspomnianego Nieświeża, pojawiają się Oszmiany oraz leżące 19 km na północny - wschód od nich Soły. Por. analizę Dariusza Fabisza w pracy D. Fabisz, Generał Lucjan Żeligowski 1865-1947 ..., s. 21, przypis nr 1. Najbardziej prawdopodobną datą urodzenia jest dzień 19 września/2 października 1865 r. Sprawę tę wyjaśnił Wasilij Jursza, który weryfikował dane genealogiczne budując kompendium wiedzy o oszmiańskich rodach szlacheckich. Odnalazł on w księgach metrycznych parafii Soły powiatu oszmiańskiego w Narodowym Historycznym Archiwum Białorusi w Grodnie ( fond 920/2/1) dokładną informację - jako datę urodzin podano 19 września 1865, folwark Przechody (Pierechody), koło Soły, http://www.oszmianszczyzna.pl/genealogia_zeligowski.html\#general (dostęp: 2.06.2019). Por. Pamiętniki generała broni Lucjana Żeligowskiego. Wstęp i oprac. D. Fabisz, Warszawa 2014, s. 7.

10 115. Wiaziemski Pułk Piechoty [115. pehotny Vjazemskij polk], z siedzibą w Rydze. Powstał w 6 kwietnia 1863 r. Święto pułku - trzeci dzień Wielkanocy. Uczestniczył w wojnie rosyjsko-tureckiej (1887-1888) i w I wojnie światowej. Rozformowany w 1917 r. Wchodził w skład 29 DP. Szersze informacje na temat rosyjskich formacji wojskowych można znaleźć w Rosyjskim Archiwum Państwowym Wojskowo-Historycznym w Moskwie (Россииिский государственный военно историzеский архи - РГВИА). 
w 136. Taganarogskim Pułku Piechoty ${ }^{11}$ w Nowoczerkasku ${ }^{12}$, a następnie w Jelizawiedgradzie (14 lipca 1903) i (13 lutego 1913 r.) w Rostowie nad Donem. 136 Taganrogski Pułk Piechoty wchodził w skład 34. Dywizji Piechoty.

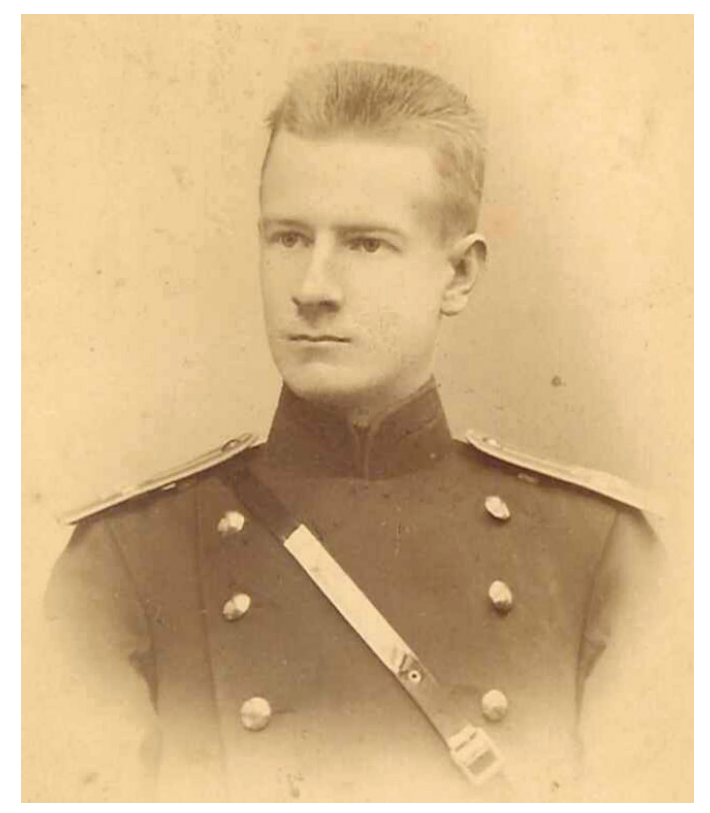

Fot.1. Lucja Żeligowski w pierwszym okresie służby wojskowej

(Źródło: Archiwum Akt Nowych w Warszawie, Zespół gen. Lucjana Żeligowskiego, sygn. 105, t. 1).

W 1904 r. wyruszył na wojnę rosyjsko-japońską, skierowany do nowotworzonego 288. Kulikowskiego Pułku Piechoty ${ }^{13}$ do Morszańska, a następnie trasą

11 136. Taganrogski Pułku Piechoty [136. pehotny Taganrogskij]. Powstał 14/27 lutego 1831 r. Święto pułku 8 lipca. Miejsce dyslokacji gubernia chersońska, Jelizawiedgrad (od 1903), następnie 1913-1914 w Rostowie nad Donem. Sztandar Pułku - Sztandar św. Jerzego z 1856 r. Z napisem »Za pacyfikację Siedmiogrodu w 1849 r. I za Sewastopol w 1854 r. i 1855 r.«.

12 B. Gumowska, op. cit., s.21.

13 288. Kulikowski Pułk Piechoty [288-j pehotnyj Kulikovskij polk]. Powstał w okresie przygotowań do wojny rosyjsko-japońskiej. W okresie I wojny światowej wchodził w skład 72. DP Armii. 
kolei transsyberyjskiej do Harbina. Jego pułk znalazł się w składzie: 72. Dywizji Piechoty, 6. Syberyjskiego Korpusu Armijnego, 2. Armii Mandżurskiej. W 1905 r. na własną prośbę został przeniesiony do 14 Pułku Strzelców ${ }^{14}$.

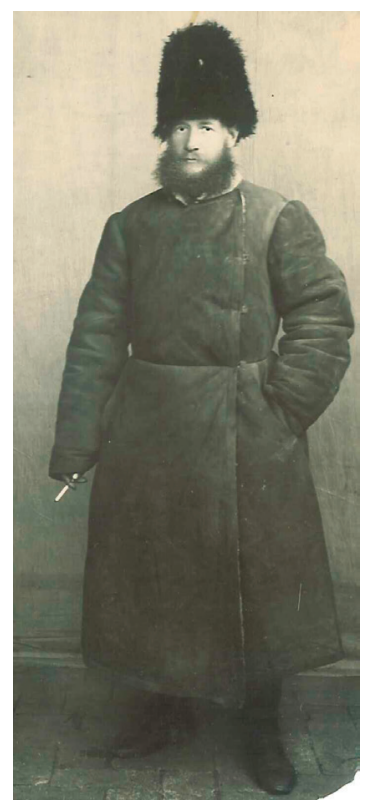

Fot. 2. Kapitan Lucjan Żeligowski - zima 1905

(AAN, Akta gen. Lucjana Żeligowskiego, sygn. 105/1, s. 8)

Żeligowski miał negatywną opinię na temat sytuacji w armii carskiej. W sporządzanych na bieżąco „Pamiętnikach”15 z wojny rosyjsko-japońskiej (1904-1905), ówczesny kapitan 288. Kulikowskiego Pułku Piechoty, zapisał: „Wszystko jakoś podupada, wali się. Brak wiedzy, patriotyzmu, poczucia obowiązku. Ludzie są bardzo nieuczciwi. Całe dowództwo to bardzo źli ludzie. Wszędzie

1414 Pułk Strzelców [14-j Strelkovyj polk general-fel'dmaršala Gurko]. Powstał 6/19 grudnia 1856 r. Święto pułku 6/19 grudnia. Dyslokowany w Odessie. Uczestniczył w wojnie rosyjsko-tureckiej oraz w tłumieniu powstania bokserów w Chinach. Brał również udział w I wojnie światowej.

15 Przygotowany przez autora artykułu, Pamiętniki gen. Lucjana Żeligowskiego z wojny rosyjsko-japońskiej 1904-1905, jest obecnie opracowywany pod względem wydawniczym. 
defraudacja pieniędzy i sprzedajność, bezprawie. I dlatego mamy ruinę, brak postępu. Dopiero teraz uświadomiłem sobie, jak bardzo potrzebne są reformy w sferze wojskowej. Nie mówię już o rządzących na szczycie, bo za mało o nich wiem. Ale widzę nasze lokalne dowództwo. Na przykład, Sobolew ${ }^{16}$. Głupi, stary, bezwolny, wszyscy bez wyjątku nim gardzą. Jak mógł dojść do takiego stanowiska? Trzeba mieć odpowiednich wujków, ciocie, itd."17. Z kolei pod datą 25 czerwca 1905 r. zanotował: „, Teraz, kiedy Polacy zaczynają walczyć o wolność i zaczynam się czuć jako równoprawny poddany, robi mi się żal Rosji. W przyszłości wróżę jeszcze więcej nieszczęść ze strony Niemiec. Żałosna biurokracja. Zamiast prowadzenia polityki słowiańskiej, zgrupowania wolnych słowiańskich narodów pod przewodnictwem Rosji, zapewnienia im większej swobody, rozwijania wolnych kultur, biurokracja zechciała stworzyć Imperium Mandżurskie, Koreańskie, jakiekolwiek, byle tylko nie zapewniać praw oraz swobód swoim obecnym poddanym. Tak, wojna była niezbędna. Bez niej nie byłoby odrodzenia narodu, uciski byłyby coraz większe. Co będzie dalej? Myślę, że Polacy mogliby być pomocni dla Rosji w poprawie obecnej sytuacji. Ale walka o wspólne interesy powinna być opłacalna. Potrzebna jest unia duchowa, która jest możliwa tylko w warunkach pełnego równouprawnienia. Musimy dążyć do tego, żeby zarówno Galicja, jak też Poznań, skierowany były w stronę Rosji. Nie powinniśmy się pytać jakiego jesteś wyznania tylko jesteś Słowianinem czy Niemcem?. Żydzi nie powinni dostać do końca równych praw. Inaczej zgarną wszystkie ziemie, wszędzie będą panami. Chociaż ich prawa powinny zostać rozszerzone. Tylko Słowianie powinni być sobie równi. Powinniśmy stworzyć Sojusz Narodów Słowiańskich pod Zwierzchnictwem Rosji”"18.

16 Leonid Nikołajewicz Sobolew, (1844-1913), rosyjski wojskowy (gen. piechoty 1903) i polityk. W latach 1882-1883 był premierem i ministrem spraw wewnętrznych Księstwa Bułgarii. Ukończył Korpus Kadetów w Petersburgu (1864) oraz kurs w Mikołajewskiej Akademii Sztabu Generalnego (1868). Uczestniczył w wojnie rosyjsko - tureckiej (walczył w bitwach pod Szopką i Plewną). Pełnił funkcje szefa sztabu moskiewskiego okręgu wojskowego. W okresie wojny rosyjsko-japońskiej stał na czele 6. Syberyjskiego Korpusu Armijnego (bitwy nad Szache i pod Mukdenem). W końcowej fazie wojny rosyjsko-japońskiej dowodził 2. Armią Mandżurską.

17 AAN, Zespół gen. Lucjana Żeligowskiego, sygn. 105/II, t.2, s. 430 - zapis z 29 maja/12 czerwca 1905 r. (tekst w języku rosyjskim w rękopisie).

18 Ibidem, s. 431. 
Klęski militarne wojsk rosyjskich w walkach z Japończykami, wstrząsnęły państwem Romanowów ${ }^{19}$. Wzrost postaw rewolucyjnych doprowadził do wybuchu protestów, których początkiem była tzw. „krwawa niedziela” (9/22 stycznia 1905 r. $)^{20}$. Wzrost postaw antycarskich zmusił Imperatora do podjęcia pierwszych działań prodemokratycznych. Stojący na czele ministerstwa spraw wewnętrznych Aleksander Bułygin ${ }^{21}$, zapowiedział udział przedstawicieli społeczeństwa w procesach ustawodawczych (koncepcja powstania Dumy) w charakterze doradców, ogłoszono również dekret o możliwości składaniu petycji do władz. Nie zahamowało to jednak dalszych działań rewolucyjnych ${ }^{22}$.

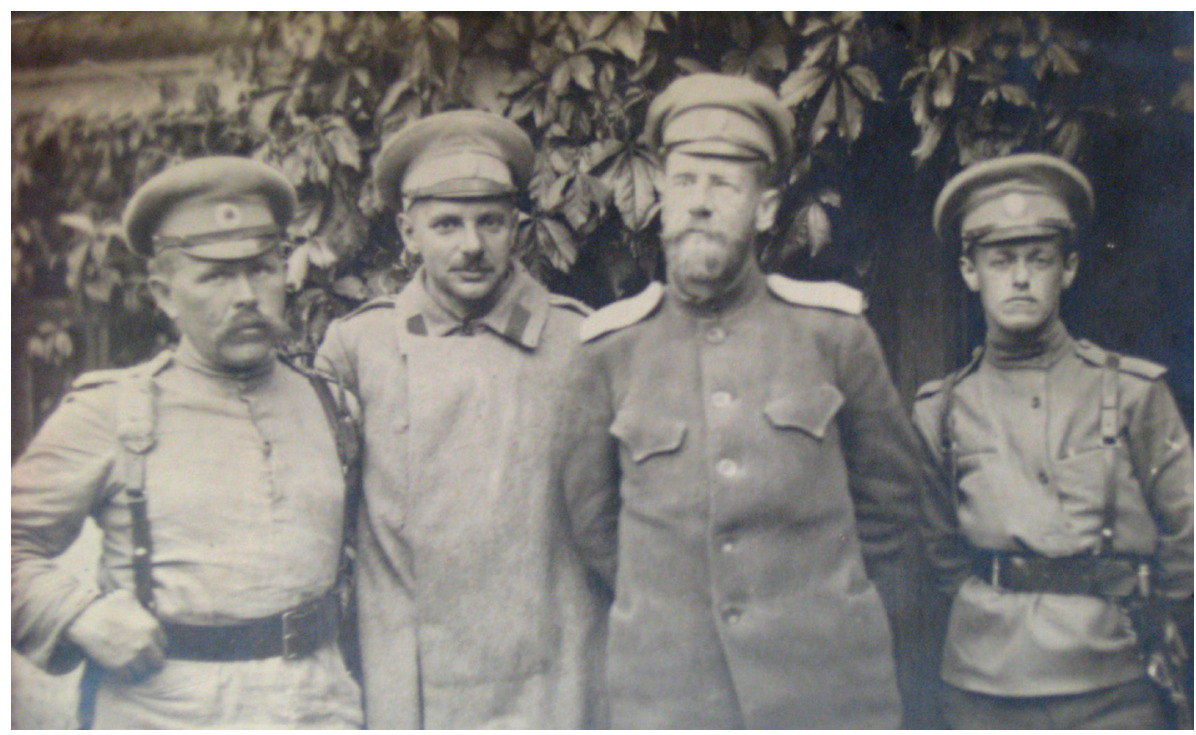

Fot. 3. Lucjan Żeligowski (trzeci od lewej) wśród carskich żołnierzy. (Źródło: AAN, Zespół gen. Lucjana Żeligowskiego, sygn., 105/II, t. 1)

19 Por. Russko-Âponskâ̂ vojna 1904-1905 gg., T. I - IX. (Русско-Японская война 1904-1905 г2. T. I - IX.), Petersburg 1910.

${ }^{20}$ L. Bazylow, P. P. Wieczorkiewicz, Historia Rosji, Wrocław-Warszawa, 2005, s. 326$-327$.

${ }^{21}$ Aleksander Grigorjewicz Bułygin, (1851-1919), rosyjski polityk, członek Rady Państwa, minister spraw wewnętrznych w okresie I-X 1905 r. Twórca idei powołania Dumy (tzw. „duma bułginowska”). Zamordowany przez bolszewików.

${ }^{22}$ L. Bazylow, P. P. Wieczorkiewicz, op. cit., s. 327-328. 
Narastająca fala strajków, której towarzyszyła świadomość klęski wojsk carskich w Mandżurii wymusiła na Mikołaju II kolejne kroki reformatorskie. Ich rezultatem był manifest cara z 17/30 października 1905 r. ${ }^{23} \mathrm{Na}$ czele rządu stanął Sergiej Witte ${ }^{24}$. Pierwsza Duma rozpoczęła swoją działalność 27 kwietnia/10 maja $1906 \mathrm{r}^{25}$.

Nastroje rewolucyjne przenikały w środowiska wojskowych. Dotarły do Żeligowskiego. Jego jawne poparcie dla zmian demokratycznych w Rosji nie spotkało się ze entuzjazmem ze strony dowództwa dywizji i korpusu. Oskarżony o działania nie godne oficera, cudem uniknął wyroku sądowego wojskowego. Niespodziewane wsparcie udzielili Polacy posłowie do I Dumy Państwowej, podejmując działania na rzecz obrony polskiego kapitana. W napisanych w latach trzydziestych XX w. „Wspomnieniach”, generał zanotował: „Wyznaczony był sąd w sprawie honorowej.[...] I wtedy zaczęły się dwa fakty które wspominam z uznaniem. 1) To sąd honorowy złożony ze starych oficerów wniósł rezolucję, że postąpiłem uczciwie zgodnie $z$ honorem oficera i nie mogłem inaczej postąpić. 2) To Koło polskie w Dumie i Senacie zwróciło się do dowódcy wojsk g. [enerała] [Aleksieja] Poliwanowa ${ }^{26}$ i wzięło mnie w obronę. Tego nie rozumiałem. Nikogo nie znałem. Do nikogo się nie zwracałem o interwencję. Jak mnie

${ }^{23}$ Car Mikołaj II wydał tzw. „Manifest październikowy”, zapowiadając amnestię dla więźniów, większe swobody obywatelskie i powstanie rosyjskiego parlamentu. - Dumy. 19 października/1. listopada 1905 r. powołano Radę Ministrów na czele z Sergiejem Witte. Por. L. Bazylow, Historia powszechna 1798-1918, Warszawa 1981, s. 800.

${ }^{24}$ Siergiej Juliewicz Witte, (1849-1915), absolwent Uniwersytetu Noworosyjskiego w Odessie (Wydział Matematyczno-Fizyczny), 1892 - minister Transportu i Finansów, 1897 - wprowadził reformę pieniężną (wymiana rubla na złoto), zwolennik budowy kolei transsyberyjskiej. W 1903 oskarżany o tzw. „spisek żydowski”. Zdymisjonowany w 1903 r. z zajmowanych stanowisk. Zwolennik ostrych działań antyrewolucyjnych i represji w okresie wydarzeń 1905 r. Od XI 1905 do IV 1906 premier rządu. Na prośbę cara doprowadził do podpisania pokoju z Japonią w Portsmouth. Po dymisji nadal współpracował z carską administracją. Przeciwnik przystąpienia Rosji do I wojny światowej.

25 Por. L. Bazylow, P. P. Wieczorkiewicz, op. cit., s. 334-337.

26 Aleksiej Andriejewicz Poliwanow (1855-1920) rosyjski wojskowy (gen. piechoty 1911); absolwent Nikołajewskiej Szkoły Technicznej (Inżynieryjnej) - 1874 oraz Nikołajewskiej Akademii Sztabu Generalnego -1888. Uczestnik wojny rosyjsko-tureckiej (1877-1878). W 1906 r. pełnił funkcję naczelnika Sztabu Generalnego. Związany z kręgami burżuazyjnymi w Dumie Państwowej Imperium Rosyjskiego. 
obecnie powiedział p.[an] Aleks.[ander] Meysztowicz ${ }^{27}$ dostałem to dlatego, że przeczytali w gazetach nazw.[isko] Lucjan Żeligowski a powiedzieli Min.[istrowi] Wojny: Polak broni waszej konstytucyi a wy go za to prześladujecie. I w tym czasie kiedy d-ca Korpusu i armii natychmiast żądali mojej dymisji, która i była zdecydowana, gdyż głosiła uzasadnienie, że kap.[itan]Ż.[eligowski]: ujemnie się stosuje do interesów Rosyi, wtedy nadeszła decyzja z Państwa od Min.[istra] Wojny ażeby umorzyć całą sprawę a mnie zrobić wymówkę za nielojalny stosunek do dow-a. Muszę się przyznać że najmniej dla mnie przyjmowaną była obrona rodaków. Dowiedziałem się o tem tylko teraz prawie 20 lat po fakcie. Nie mogłem zrozumieć kiedy co się stało.

Nikt mnie nie znał. Poglądy moje polit.[tyczne] były znacznie radykalniejsze od pog.[lądów] naszego pułku, a jednakże bronili mnie. I jak dużo było wypadków. Wiem o tem jak g.[raf]a [Bogdana Jaxę -] Ronikier.[a] ${ }^{28}$ bronił Dzierżyński ${ }^{29}$, jak cały szereg zawziętych bolszewków Polaków broniło polskiego oficerów. I w tem jest nasza siła. Krew nie woda" ${ }^{30}$.

Żeligowski zdawał sobie sprawę, że służba wojskowa Polaków w armii carskiej nie spotyka się z powszechną aprobatą. Generał podkreślał, że: „Polak w armii rosyjskiej pozbawiony był możliwości wyższego wykształcenia wojskowego. Nie mógł skończyć wyższej szkoły wojennej. Nie mógł zajmować całego szeregu stanowisk sztabowych. Mógł być tylko i wyłącznie oficerem liniowym" 31 .

${ }^{27}$ Aleksander Meysztowicz, (1864-1943), ziemianin, polityk. W latach 1900-1904, m.in. prezes Towarzystwa Rolniczego Koweńskiego. W latach 1909-1917 w Radzie Państwa Imperium Rosyjskiego. W okresie istnienia Litwy Środkowej prezes Tymczasowej Komisji Rządzącej Litwy Środkowej i minister sprawiedliwości. W II Rzeczypospolitej pełnił funkcję ministra sprawiedliwości w rządach Józefa Piłsudskiego i Kazimierza Bartla. Od 1933 tajny szambelan papieski.

${ }^{28}$ Bogdan Maria Wincenty Jaxa-Ronikier, (1873-1953), hrabia, pisarz, oskarżony o zabicie swego szwagra Stanisława Chrzanowskiego, skazany na zesłanie. Ostatecznie ułaskawiony w II RP przez prezydenta Ignacego Mościckiego w 1927 r. Autor m.in. pracy Dzierżyński. „Czerwony kat”, Warszawa 1933. We książce Bogdan Jaxa-Ronikier wspominał m.in. swoje spotkania z Feliksem Dzierżyńskim.

${ }^{29}$ Feliks Dzierżyński (1877-1926), polski i rosyjski działacz komunistyczny, rewolucjonista. W ZSRS organizator sowieckich instytucji bezpieczeństwa, CZeKa, GPU i OGPU. Jeden z twórców państwa sowieckiego.

${ }^{30}$ Całość tekstu: AAN Zespót gen. Lucjana Żeligowskiego, sygn. 105/II, t. 3 , s. 159-165.

${ }^{31}$ L. Żeligowski, Wojna w roku 1920. Wspomnienia i rozważania, Warszawa 1930, s.14. 
Po wojnie rosyjsko-japońskiej Żeligowski powrócił do służby w 136. Taganarogskim Pułku Piechoty, wysłano go do małego garnizonu w rejonie Żymerynki, gdzie pełnił funkcję dowódcy kompanii. W 1912 r. został konspiracyjnym działaczem Związku Walki Czynnej (w Rosji) ${ }^{32}$. W okresie I wojny światowej służył w 284. Węgrowskim Pułku Piechoty - został uzupełniony żołnierzami 136. Taganarogskim Pułku Piechoty ${ }^{33}$. Z legionistami Żeligowski spotkał się w czasie walk w Karpatach na pograniczu Węgier i Galicji w 1914 i 1915 r. Oddziałami II Brygady Legionów (pod Kirlibabą) dowodził gen Zygmunt Zieliński, skutecznie przeciwstawio się rosyjskim atakom ${ }^{34}$. Po decyzji głównodowodzącego wojsk carskich Michaiła Aleksandrowicza z 22 września 1915 r. na formowanie polskich oddziałów przy armii carskiej, zaczęto w Bobrujsku tworzyć Brygadę Strzelców Polskich (BSP) w której dowódcą II batalionu został płk Lucjan Żeligowski ${ }^{35}$. Oddziały Brygady przeszedły „chrzest bojowy” nad rzeką Szczarą (27 lipca 1916 r.) pod miejscowością Zaosie, uderzając na pozycje niemieckie ${ }^{36}$.

Po upadku caratu, władze rosyjskie wyraziły zgodę na powstanie organizacji skupiającej polski ruch wojskowy ${ }^{37}$. Od marca 1917 r. powstawały w Rosji Związki Wojskowe Polaków a w czerwcu 1917 r. podjęto decyzję o utworzeniu Polskiej Siły Zbrojnej i Naczelnego Polskiego Komitetu Wojskowego (Naczpolu). W dniu 24 styczniu 1917 r utworzono 1.Dywizję Strzelców Polskich. Dowodzony przez Żeligowskiego 1 pułk strzelców walczył na Froncie Galicyjskim, bronił m.in. (w dniu 28 lipca 1917 r.) przeprawy pod Husiatynem nad Zbruczem ${ }^{38}$. Waleczność Żeligowskiego podkreślał, opisujący walki o przyczół-

32 Porównaj rozbieżne opinii na ten temat K. Galas, Generał broni Lucjan Żeligowski ...,

33 284. Węgrowski Pułku Piechoty [284. Vengrovskij pehotny polk] - powstał w 1892 r. jako rezerwowy 191/190 Pułk Piechoty. W okresie I wojny światowej wchodził w skład 2 brygady w 71. Dywizji Piechoty.

34 B. Gumowska, op.cit., s.30.

${ }^{35}$ M. Wrzosek, Polski czyn zbrojny podczas I wojny światowej 1914-1918, Warszawa 1990, s.281.

${ }^{36}$ M. Marczuk, op. cit., s.45

37 Rozkaz nr 1 Piotrogrodzkiej Rady Delegatów Robotniczych i Żołnierzy z 14 marca 1917 r. oraz Tymczasowe Zarządzenie głównodowodzącego armii rosyjskiej z 30 marca 1917 r. o organizacji władz armii czynnej i floty oraz rozkaz nr 114 ministra wojny Aleksandra Guczkowa z 31 marca 1917 r. Por. T. Kaźniewski, Wojsko Polskie w Rosji w czasie rewolucji 1917-1918, Warszawa 1935, s.20.

38 Szerzej, H. Bagiński, Wojsko Polskie na Wschodzie; 1914-1920, Warszawa 1921, s. $68-71$. 
ki mostowe nad Zbruczem, płk Henryk Bagiński: „Z ostatnią grupą walczących cofał się Żeligowski, który swoją powagą męstwem i spokojem zjednywał sobie, w całym ciężkim okresie działań bojowych Dywizji Strzelców Polskich, stanowisko wielce poczesne i zaszczytne" ${ }^{39}$. Następnie Żeligowski znalazł się w I Korpusie Polskim (I KP) dowodzonym przez gen. lejtnanta Józefa Dowbora - Muśnickiego. Od lutego 1918 r. Żeligowski dowódził 1. Dywizją. Wszedł jednak w konflikt z gen. Józefem Dowborem-Muśnickim. W przeciwieństwie do dowódcy nie popierał idei wspierania Rządu Tymczasowego. Był zdania, że Polacy powinni być neutralni wobec konfliktu w Rosji. Mieszanie się I KP w sprawy rosyjskie spotykało się ze sprzeciwem wielu oficerów w tym i Żeligowskiego. We Wspomnieniach gen. Dowbór -Muśnicki, ostro krytykował Żeligowskiego, zarzucając mu nieudolność w walkach z bolszewikami pod Żłobinem: „Pułk. Żeligowski wykazał tu swoją nieudolność. Trafił do korpusu nie z mego wyboru lecz z rekomendacji "Naczpolu», będąc sam jego członkiem. Miał reputację «dobrego patrioty» i nosił najwyższą odznakę za waleczność , oficerski krzyż św. Jerzego [...] pod Żłobinem talentów żadnych nie wykazał. Czy po prostu nie mógł dać sobie rady z dwoma pułkami" ${ }^{40}$. Pułkownik Żeligowski podał się do dymisji. Nieoczekiwanie ze strony dowódcy Korpusu gen. Dowbora-Musnickiego otrzymał podziękowania za służbę dobrą służbę. W odpowiedzi gen. Dowborowi-Muscickiemu, Żeligowski napisał: „Za służbę ojczyźnie NIK nie potrzebuje cudzego podziękowania. Lecz jeżeliby to podziękowanie komuś należeć się miało, to p. Generał jest najmniej uprawnioną osobą, któryby to podziękowanie udzielać mogła" ${ }^{21}$. Były to ostatnie dni funkcjonowania Korpusu. W dniu 21 maja 1918 r., po porozumieniu gen. Dowbora-Muśnickiego ze stroną niemiecką I KP rozformowano ( w twierdzy Bobrujsk) a żołnierze zostali podporządkowani Radzie Regencyjnej Królestwa Polskiego. Większość z nich po powrocie do Warszawy weszła w skład powstającego Wojska Polskiego.

Żeligowski wyjechał na Krym a następnie na Kubania, gdzie zaczęto tworzyć polskie oddziały wojskowe. Formalnie od 24 sierpnia 1918 r. rozpoczęto formułowanie polskich oddziałów wojskowych. Do Jekaterinodaru na Kubaniu płk Żeligowski przybył w dniu 6 października 1918 r. W dniu 20 października 1918 r. został mianowany dowódcą Wojska Polskiego w Rosji, które podlegało

\footnotetext{
39 Ibidem, s. 71.

40 J. Dowbór-Musnicki, Wspomnienia, Warszawa 2003, s. 176

41 AAN, Lucjan Żeligowski, sygn. 105/II, t.46.
} 
dowództwu Armii Polskiej we Francji (równocześnie mianowano go generałem podporucznikiem). Od 27 października 1918 r. współdziałał z rosyjską Armią Ochotniczą (gen. Antona Denikina) w walkach z bolszewikami (Tarnówka, Aleksandrówka, Bezopasnoje, Donskoje, Worowska-Bałka, Wielkaja-Bałdża, Małaja Agałdza) ${ }^{42}$. Był organizatorem i dowódcą 4. Dywizji Strzelców Polskich (DSP). Do Polski dywizja powrócił, po rozkazie gen. Hallera z listopada 1918 r. via Odessa i Besarabia w czerwcu 1919 r. Natychmiast włączyła się w działania wojenne wojny polsko-ukraińskiej, broniąc Stanisławowa i Halicza. Do historii przeszły walki w rejonie linii rzeki Strypy, gdzie w walkach pod Jazłowcem wyróżnił Pułk Ułanów (14. Pułk Ułanów Jazłowieckich).

Służbę wojskową w Wojsku Polskim rozpocząła generał jako dowódca 10. Dywizji Piechoty (przemianowana z 4. DSP). W okresie wojny polsko-sowieckiej walczył w bitwie nad Autą; w obronie linii Niemna - dowodził Grupa Operacyjną (10. Dywizja Piechoty oraz 1. Dywizja Litewsko-Białoruska); nad Narwią w walkach z 15. Armią Sowiecka; w walkach w obronie przedmieścia Warszawy - 10 DP gen. Żeligowskiego odegrała ważną role w walkach pod Radzyminem, odrzucając dywizje bolszewickie (27., 2. i 21.) poza linię rzeki Rządzy. Zdobyli Radzymin, niemal całkowicie rozbijając przy tym 27. Dywizję bolszewicką ${ }^{43}$. Walki Żeligowski zakończył 22 sierpnia 1920 r. w Ciechanowie (po pościgu za wojskami sowieckimi).

Marszałek Piłsudski był dość krytyczny w opiniowaniu generała. Oceniając w 1922 r. generalicję Wojska Polskiego, tak scharakteryzował Żeligowskiego: „Pod względem charakteru dowodzenia. Człowiek o silnym charakterze, lecz z powodu braku wykształcenia wojskowego i obycia w dowodzeniu bardziej samodzielnym i niepewnym siebie. Ma zły zwyczaj pytana wszystkich o zdanie i radę. Jeżeli świadczy to o nim dobrze jako człowieku, to w dowodzeniu może łatwo zabić jego autorytet, a w każdym razie opóźnia znakomicie pobranie jakichkolwiek decyzji. Potrzebuje koniecznie takiego otoczenia, którego by się nie wstydził pytać nawet o najdrobniejsze rzeczy. W boju jest to generał pewny i dopóki trwa bój, nawet jego wady nie są niebezpieczne. Natomiast w pracy wyższego dowództwa będzie chwiejny i będzie łatwo ulegał chwilowym pomysłom nieraz najbardziej dziwacznym. W stosunku do podwładnych jest trochę za względny i rozsądnie podzielić roboty nie potrafi. Jest dobrym, honorowym

42 D. Fabisz, Generał Lucjan Żeligowski, s. 62.

43 A. Suchcitz, Generałowie wojny polsko-sowieckiej 1919-1920, Białystok 1993, s. 90. 
żołnierzem, tak że nawet jego wady, jak pewna doza próżności i upór rasy wileńskiej, ustępują łatwo pod naciskiem dyscypliny wewnętrznej i imperatywnego nakazu niesienia służby dobrze. Pod względem objętości dowodzenia. Może dowodzić armią, z warunkiem żeby się czuł pewny swego szefa sztabu w dziedzinie operacyjnej i zarządu Tylami. Szef sztabu musi być tak do niego dobrany, żeby się czuł z nim dobrze osobiście. Lepszy zawsze jest do użycia na froncie niż na tyłach" 44

Ważnym elementem biografii gen. Żeligowskiego są jego działania polityczno-militarne związane z utworzeniem Litwy Środkowej. Konflikt polsko-litewski o granice po pertraktacjach ze stroną litewską z 7 października $1920 \mathrm{r}$. regulowała tymczasowa umowa ${ }^{45}$, która dotyczył kształtu granicy w rejonie Suwalszczyzny, nie obejmowała jednak obszaru Wileńszczyzny. Miała wejść w życie 10 października. Artykuł 5 umowy zakładał, że miała ona obowiązywać do czasu ostatecznego uregulowania sporów terytorialnych pomiędzy Rządem Polskim a Litewskim ${ }^{46}$.

W dniu 2 października 1920 r. Żeligowski został dowódcą Grupy Operacyjnej Bieniakonie $^{47}$. Grpa podlegała dowódcy 3 Armii gen. Władysławowi Sikorskiemu. W dniu 8 października Sikorski otrzymał depeszę: „Do dowództwa armii do rąk własnych dowódcy. Tajne, bardzo pilne.Zważywszy, że zawarte z rządem kowieńskim linie rozejmowe z góry i na niekorzyść nas, mieszkańców ziemi wileńskiej, grodzieńskiej i lidzkiej, nas, wraz z polskiem Wilnem przysądzały Litwinom, postanowiłem z orężem w ręku, prawa samostanowienia mieszkańców mojej ojczyzny obronić i objąłem dowództwo nad żołnierzami z tych ziem pochodzącymi, nie mając możności postępować wbrew własnemu sumieniu i poczuciu obowiązku obywatelskiego. Z żalem zgłaszam zwolnienie z od obowiązków służby i dowództwa grupy. Wychowani w karności i wierni idei wyzwolenia ojczyzny podlegli mi dowódcy i wojska słuchają moich roz-

${ }^{44}$ M. Cieplewicz, Generałowie polscy w opinii J. Piłsudskiego, „Wojskowy Przegląd Historyczny" 1966, nr 1, s.330-331.

45 Umowa między Rzecząospolitq Polskq i Rzecząpospolitq Litewskq w sprawie ustanowienia tymczasowego modus vivendi aż do ostatecznego uregulowania stosunków między oboma państwami podpisana w Suwałkach, dnia 7 go października 1920, [w:] League of Nations Treaty Series, 1922, vol. VIII, nr 221.

46 Ibidem, art.5., s.179.

47 W jej skład wchodziły1 Dywizja Litewsko-Białoruska, 12. i 211. pułki ułanów oraz oddział ochotników mjr. Mariana Zyndrama -Kościałkowskiego. 
kazów, a dla pozostawionych oddziałów proszę wydać bezpośrednie rozkazy. Miejsce postoju dnia 8 października 1920 r. Żeligowski, generał i dowódca grupy" $^{48}$. Za wiedzą Józefa Piłsudskiego, po upozorowaniu niesubordynacji wobec Naczelnego Wodza, w dniu 9 października 1920 r., na czele „zbuntowanych” oddziałów 1. Dywizji Litewsko-Białoruskiej gen. Żeligowski, zajął Wilno i doprowadził do utworzenia tzw. Litwy Środkowej ${ }^{49}$. W odezwie do ludności, generał Żeligowski napisał: „Rodacy! Nie możemy dopuścić do tego, aby krajem naszym handlowano jak bezdusznym towarem lub sprzętem, aby rząd litewski wbrew woli naszej otrzymywał tę ziemię od wrogów naszej Ojczyzny w zamian za usługi oddawane im w walce z Polską. Nie chcemy wojny z państwem litewskiem; z narodem litewskim pragniemy żyć w zgodzie i porozumieniu; nie dopuścimy jednak, aby wbrew naszej woli z rąk odwiecznego wroga Polski i Litwy narodowy rząd litewski obejmował władzę nad polskiem Wilnem" ${ }^{50}$. Generał został Naczelnym Dowódcą Wojsk Litwy Środkowej. W dniu 30 listopada 1921 r. ukazał się dekret gen. Żeligowskiego, w którym ogłosił wybory do Sejmu Litwy Środkowej (8 stycznia 1922 r.), a następnie Sejm Litwy Środkowej (na swym 10 posiedzenie - 20 lutego 1922 r.) proklamował przyłączenie tych obszarów do Polski ${ }^{51}$. Czy było możliwe rozstrzygniecie dyplomatyczne dotyczące przynależności Wileńszczyzny? „Przebieg wypadków, poprzedzających czyn gen. Żeligowskiego, był wymownym dowodem, że akcja dyplomatyczna o Wilno nie dałaby żadnych rezultatów, gdyby nie została poparta tak wymownym argumentem, jak działania wojenne"52.W dniu 30 listopada $1921 \mathrm{r}$.

48 Był to swego rodzaju kamuflaż, ułatwiający Piłsudskiemu gry dyplomatyczne. Por. B. Waligóra, Zajęcie Wilna przez gen. Żeligowskiego, „Bellona”, T.36, 1930, s. 248

49 Por. L. Żeligowski, Zajęcie Wilna w roku 1920, komentarz i wyd. T. Stańczyk, „Rzeczpospolita”, 1992, nr 57.

50 Dziennik Tymczasowej Komisji Rządzącej. Litwa Środkowa, Wilno dnia 28 listopada 1920, Nr 4. Archiwum Instytutu Józefa Piłsudskiego w Ameryce (AIJPA), Adiutantura Generalna Naczelnego Wodza. Rozkaz Nr 1 Naczelnego Dowództwa Wojsk Litwy Środkowej i Odezwa Komisji Rządzącej Litwy Środkowej do ludności., sygn. 701/2/28, s. 102.

51 Sejm Wileński 1922. Przebieg posiedzeń według sprawozdań stenograficznych w opracowaniu kancelarii sejmowej, Wilno 1922, X posiedzenie Sejmu z 20 lutego 1922, s. X/1-22.

52 W.P. Akcja zbrojna i dyplomatyczna o Wilno, w: Wilno wyzwolone. Jednodniówka na zjazd bytych uczestników walk o Wilno w dniach 10-11 XI.1930 r. Wilno 1930, s. 10 
Naczelnik Państwa (z dniem 1 grudnia 1921 r.) awansował Żeligowskiego na stopień generała porucznika (dywizji) ${ }^{53}$.

W okresie od 1 listopada 1921 r. do 27 listopada 1925 r. gen. Żeligowski pełnił funkcje Inspektorem Armii nr 2 w Warszawie. Swoją decyzje o objęciu dowództwa Inspektoratu nr 2 Żeligowski tłumaczył interwencją gen. Kazimierza Sosnkowskiego, ówczesnego Ministra Spraw Wojskowych, który „wyraził obawę, że moje odejście bezpośrednio po zakończeniu sprawy wileńskiej, obfitującej w przeróżne tarcia, poczytane będzie za demonstrację polityczną"54. W dniu 31 marca 1924 r. prezydent Stanisław Wojciechowski awansował Żeligowskiego na stopień generała broni (starszeństwo z dniem 1 lipca 1923 z 1. lokatą w korpusie generałów) ${ }^{55}$.

Generał był rozczarowany możliwościami działania inspektorów armii, posiadający niewiele praw i nie ponoszący odpowiedzialności. Zauważał niekompetencje na różnych stanowiskach wojskowych. Marian Romeyko, przytoczył wręcz legendarną wypowiedź Żeligowskiego o rozmywaniu się kompetencji na wyższych stanowiskach wojskowych. Romeyko pisał: „Pamiętam, jak Żeligowski, po wizycie u szefa administracji armii, którym podówczas był generał lekarz Zwierzchowski ${ }^{56}$, tak się wypowiedział: » Idę ja, znaczy się do szefa Administracji Armii myślę, ze to gienierał... a widzę, że to siedzi dantist«"57.

53 „Dz.P.”, Nr 3 z 25 lutego 1922 r., s.142,

54 Pamiętniki generała broni Lucjana Żeligowskiego..., s. 39-40. Por. AIJPA, Adiutantura Generalna Naczelnego Wodza, Pismo od gen. Sosnkowskiego do gen. Lucjana Żeligowskiego, sygn. 701/2/13, s.82-84.

55 Dz. P. Nr 32 z 2 kwietnia1924, s.165.

56 Franciszek Zwierkowski (1873-1949) generał brygady, lekarz o rodowodzie z armii rosyjskiej. W carskiej Rosji był m.in. profesorem w Instytucie Medycznym dla kobiet i Instytucie Psychoneurologicznym w Petersburgu oraz kierownikiem Kliniki Stomatologicznej Akademii Wojskowo-Medycznej - w randze pułkownika. W Wojsku Polskim był (1924-1925) I zastępcą szefa Administracji Armii. Od 1927 - w stanie spoczynku.

57 M. Romeyko, Przed i po maju, Warszawa 1967, s. 446, przypis 1. 


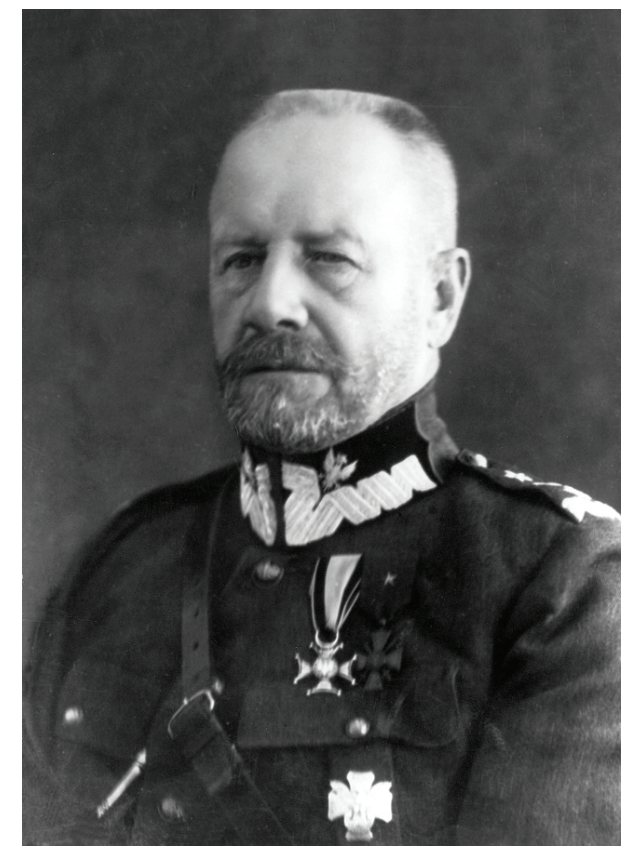

Fot.4: Generał dywizji Lucjan Żeligowski.

(Źródło; NAC)

Wzrost politycznego napięcia w Polsce pomiędzy zwolennikami i przeciwnikami Marszałka, tworzył sytuację, która nadawała coraz ostrzejszy wymiar konfliktowi, prowadząc do ostatecznej konfrontacji. Gen. Lucjan Żeligowski od 27 listopada 1925 do 5 maja 1926 r. pełnił funkcje ministra spraw wojskowych (w rządzie Aleksandra Skrzyńskiego). Jednym z pól sporów była przygotowywana przez różnych generałów (np. Stanisław Szeptycki, Władysław Sikorski) ustawa o naczelnych władz wojskowych. Żaden z pomysłów nie był akceptowany przez Piłsudskiego. Swój projekt przygotował również gen. Lucjan Żeligowski, który był najbliższy poglądom Marszałka. Zakładał m.in. ze generalny inspektor wojsk w czasie wojny staje się automatycznie Naczelnym Wodzem. Z kolei w czasie pokoju miał pełnić role wiceministra Spraw Wojskowych. Podporządkowywano mu szefa Sztabu Generalnego ${ }^{58}$ Powszechnie uważa się, że w

58 Projekt spotkał się z ostrą krytyka ze strony gen. Tadeusza Rozwadowskiego oraz marszałka Senatu Wojciecha Trąbczyńskiego. Ten ostatni podważał kompetencje Mar- 
znaczny sposób ułatwił zwolennikom Marszałka przygotowanie do zamachu. Istnieje przekonanie, że Żeligowski zaangażował się po stronie zwolenników Marszałka. Doprowadził m.in. do powrotu na stanowisko dowódcy 2. Dywizji Kawalerii gen. Gustawa Orlicz-Dreszera. Generał Orlicz-Dreszer - był przeniesiony do Poznania (na stanowisko dowódcy 3.DK) za manifestowanie poparcia dla Piłsudskiego w czasie demonstracji w dniu 15 listopada 1925 r. w Sulejówku z okazji siódmej rocznicy powrotu Marszałka z Magdeburga ${ }^{59}$. Dreszer kary nie traktował poważnie, udał się na samowolny urlop, lekceważąc wszelkie rozkazy. Uważał, że powodem jego przeniesienia do Poznania nie było wystąpienie w Sulejówku, ale zachowanie podczas sądu honorowego w sprawie między Marszałkiem a gen. Stanisławem Hallerem ${ }^{60}$. Żeligowski „pozbył się” z Warszawy gen. Władysława Sikorskiego, mianując go dowódcą Okręgu Korpusu nr VI we Lwowie. W grudniu 1925 r. ze stanowiska szefa Sztabu Generalnego zwolniono gen. Stanisława Hallera. Żeligowski zdymisjonował także przeciwnika Piłsudskiego gen. Włodzimierza Zagórskiego ze stanowiska szefa Departamentu Aeronautyki MSWojsk. W dotychczasowej literaturze wskazywano również na wydanie przez Żeligowskiego rozkazu (18 kwietnia 1926 r.) o koncentracji ( na dzień 10 maja) wojska w rejonie Rembertowa w celu przeprowadzenia gier wojennych, co miało sprzyjać Piłsudskiemu ${ }^{61}$. Warte uwagi w kwestii przygotowań do zamachu majowego jest inne spojrzenie autorstwa Włodzimierza Suleji, odrzucające takie supozycje, i podważające istnienie wspomnianego rozkazu, dające inne spojrzenie na rolę gen. Żeligowskiego ${ }^{62}$.

Po przewrocie majowym w dniu 15 maja 1926 r. Piłsudski wydał rozkaz o powołaniu Komisji Likwidacyjnej z gen. broni Lucjanem Żeligowskim na czele, której celem było „zlikwidowanie wypadków majowych” (18 maja 1926 r.).

szałka do pełnienia takiej funkcji, co jeszcze bardziej zaostrzało spory. Por. L. Wyszczelski, Ministerstwo Spraw Wojskowych (1918-1939), Warszawa 2010, s. 129-130.

59 Por. AAN, Zespół gen. Żeligowskiego..., t.26, s. 20-22, także: Nr 10, 1925.12.01, Poznań. Pismo dowódcy Okręgu Korpusu nr VII gen. dyw. K. Sosnkowskiego do ministra spraw wojskowych gen. broni L. Żeligowskiego w sprawie gen. G. Orlicz-Dreszer, [w:] Z. Cieślikowski, Materiaty źródłowe do przewrotu majowego, Warszawa 2002, s. 95-96.

60 Por. K. Wrzos, Piłsudski i piłsudczycy, Warszawa 1936., s.67.

61 Por. L. Żeligowski, Przewrót majowy, [w:] Warszawa w II Rzeczypospolitej 1918-1939, red. M. Drozdowski, E. Borecka, H. Janowska, Warszawa 1970, z. 2, s. 194, 199; S. Haller, Wypadki warszawskie od 12 maja do 15 maja 1926, Kraków 1926, s. 98.

62 Por. W. Suleja, Zamach majowy, [w:] Polski wiek XX. Dwudziestolecie, pod red. K. Persaka i P. Machcewicza, Warszawa 2009, s.139. 
Do zadań stawianych Komisji należało ${ }^{63}:$ 1) doprowadzenie oddziałów do normalnego stanu; 2) likwidacja i rozbrojenie organizacji przysposobienia wojskowego „Strzelec” i młodzieży akademickiej; 3) przedstawienie na podstawie sprawozdań oddziałów szefa sanitarnego OK. i Polskiego Czerwonego Krzyża, strat ludzkich: zabitych i rannych żołnierzy oraz osób cywilnych; 4) ustalenie wszystkich strat powstałych w skutek wydarzeń; 5) załatwienie spraw personalnych, honorowych i karnych, łączących się z wypadkami.

Po przejęciu kontroli nad państwem i armią Józef Piłsudski podjął decyzję o dwutorowym system zarządzania wojskiem. W czasie pokoju za organizację WP odpowiadał minister spraw wojskowych a w okresie wojny Naczelnym Wodzem miał zostać Generalny Inspektor Sił Zbrojnych. Pełniący obie funkcje równocześnie (ministra spraw wojskowych i Generalnego Inspektora Sił Zbrojnych) Marszałek, mianował Żeligowskiego inspektorem armii (od 14 października do 31 sierpnia 1927 r.). Z końcem sierpnia 1927 r. na własną prośbę generał przeszedł w stan spoczynku i zamieszkał w Andrzejewie, zjmując się hodowią $\ln u^{64}$.

W 1928 r. Żeligowski został prezesem Kapituły Orderu Polonia Restituta, a w 1929 r. członkiem Trybunału Stanu. Działał aktywnie w środowiskach kombatanckich, był prezesem Związku Żołnierzy I Korpusu Wschodniego ${ }^{65}$. W 1935 r. został wybrany posłem na Sejmu IV kadencji z listy Bezpartyjnego Bloku Współpracy z Rządem - przewodniczył Komisji Wojskowej, a następnie posłem na Sejmu V kadencji z listy bezpartyjnej. Po śmierci Marszałka znalazł się w opozycji do Obozu Zjednoczenia Narodowego. Był zwolennik powołania (1938 r.) rządu obrony narodowej.

W okresie II wojny światowej starał się o powrót do służby czynnej (wrzesień 1939 r.) - lecz nie uzyskał zgody. Przez pewien czas towarzyszył dowódcy

63 A. Garlicki, P. Stawecki, Przewrót wojskowy w Polsce 1926 r. Wybór dokumentów, cz. I, „Wojskowy Przegląd Historyczny” 1977, nr 2, s. 230. Por. B. Woszczyński, Wypadki majowe 1926 roku w liczbach, „Najnowsze Dzieje Polski. Materiały i Studia z okresu 1914-1939”, 1966, t. X, s.235-236.

64 Majątek miał być podarowany generałowi za zdobycie Wilna. Miał on 100 ha ziemi i łąk. Sam majtek był w podupadłym stanie. Po przejściu w stan spoczynku, Żeligowski inwestował w jego rozwój. Władze Litewskiej SRR chciały majątek nacjonalizować. Ostatecznie gospodarstwo przejął, szwagier Żeligowskiego - Litwin. Por. W. Marczyk, op. cit. 44, 49; D. Fabisz, Generat...,s. 222 i n.

65 W. Marczyk, op. cit., s. 49. 
Frontu Południowego gen. broni Kazimierza Sosnkowskiego, następnie znalazł się na emigracji (Francja i Wielka Brytania), był m.in. członkiem Rady Narodowej RP, przewodniczącym jej Komisji Wojskowej oraz Kanclerzem Kapituły Orderu Virtuti Militari.

Przez całe życie Lucjan Żeligowski był zwolennikiem idei słowianofilskiej. Najwyraźniej kwestie te były widoczne w głoszonych przez generała poglądach w okresie II wojny światowej. Był zdania, że konfrontacja z III Rzeszą doprowadzi do przebudzenia Słowian, a po wojnie Polska przesunie swoje granice na Zachód w kierunku Odry, Łaby i Szczecina. Usprawiedliwiał agresję sowiecką na Polskę uważając, że Rosjanie chcieli zająć Ukrainę, by powstrzymać masz Niemców na Kaukaz i Ural. Wygłaszanymi przez siebie poglądami zrażał sobie wielu Polaków na emigracji66 ${ }^{6}$ W 1943 r. głosił opinie o pojednaniu z wkraczającymi na tereny polskie Sowietami, zauważył, że to armia Słowian a więc powinniśmy ich traktować, jak braci. Słowianie muszą znaleźć wspólny język, doprowadzić do wzajemnego porozumienia. Drogą do takiego porozumienia miało być, m.in. włączenie do rządu Mikołajczyka przedstawicieli Związku Patriotów Polskich i działaczy lewicowych organizacji ruchu oporu w Polsce. Był zwolennikiem powrotu z Zachodu do kraju, polskich żołnierzy ${ }^{67}$.

Po wojnie zamieszkał w Wielkiej Brytanii. Zmarł 9 lipca 1947 r. w Londynie. Jego ciało przewieziono do Polski (na jego prośbę) 12 lipca 1947 r., został pochowany na cmentarzu Powązkowskim w Warszawie, Aleja Zasłużonych (A 25, mogiła 23). W czasie przewożenia jego zwłok do Polski, gen. Stanisław

66 Szczególnie było to widoczne w ocenach Stanisława Cata Mackiewicz, który uważał Żeligowskiego za bohatera Wilnian. (por. S. Mackiewicz (Cat), Generał Żeligowski, „Słowo”, 1930, nr 232). Z niezrozumieniem, podobnie jak większość emigracji podchodził do głoszonej przez Żeligowskiego miłości do Sowietów. Uważano, ze generała, mającego 80 lat opanowało maniakalne słowianofilstwo. Rozgoryczony Mackiewicz pisał. m.in.; „.Jaka szkoda, że gen. Żeligowski nie umarł w Wilnie. Nie byłoby wtedy mogły tak wysojkiej, której by mu lud wileński nie usypał. Dziś czeka go grób wspólny z Wandom Wasilewską z prof. [Oskarem] Lange”.S. Mackiewicz (Cat), Lata nadziei...,s.154.

67 Szerzej na temat idei słowianofilskich głoszonych przez gen. Żeligowskiego pisze m.in. D. Fabisz, Generał Lucjan Żeligowski..., s.322 i n. Bardzo negatywnie na temat Żeligowskiego wypowiadał się Stanisław (Cat ) Mackiewicz, który pisał: „Jaka szkoda, że gen. Żeligowski nie umarł w Wilnie. Nie byłoby wtedy mogiły tak wysokiej, której by mu lud wileński nie usypał. Dziś czeka go grób wspólny z Wandą Wasilewską, z prof. [Oskarem] Lange i innymi agentami obcego nam rządu". S. (Cat ) Mackiewicz, Lata nadzieii 17 września 1939 r.-5 lipca 1945 r., Warszawa 1990, s. 154. 
Tatar przemycił do kraju część zdeponowanych w Wielkiej Brytanii zasobów Funduszu Obrony Narodowej.

Lucjan Żeligowski pierwsze stopnie oficerskie otrzymał w armii carskiej: podporucznik - 1888, por. - 9/22 stycznia 1897 r., kapitan sztabu - 5/18 czerwca 1900, kapitan - 1904, podpułkownik - styczeń 1915 r., pułkownik - 5/18 czerwca 1915 , gen. ppor. - 1918 r. (mianowany przez gen. ppor. Józefa Hallera); gen. por. (dyw.) - starszeństwo - 1.06.1919, lok. 1; gen. broni 1924 - starszeństwo - 1.07.1923, lok. 1.

Generał Lucjan Żeligowski był żonaty z Tatianą Pietrową (prawdopodobnie prawdziwe nazwisko - Łopatto). Miał dowje dzieci - Janinę i Tadeusza ( urodzeni w 1908 r.).

W armii carskiej odznaczony Orderem Świętego Jerzego IV kl., Order św. Włodzimierza z Mieczami IV kl., Order św. Anny II kl., Order św. Anny III kl., Order św. Stanisława II kl. W Wojsku Polskim Orderem Virtuti Militari 2. i 5. kl.; Polonia Restituta 1.kl., Krzyżem Walecznych 4-krotnie, francuską Legią Honorową - komandorska (nr 2143), Krzyżem Zasługi Wojsk Litwy Środkowej, Medalem Pamiątkowy za Wojnę 1918-1921, Medalem Dziesięciolecia Odzyskanej Niepodległości, Medalem Międzysojuszniczy „Médaille Interalliée”.

\section{Zakończenie}

Generał Lucjan Żeligowski wywodził się z polskiego rodu szlacheckiego, herbu „Bończa”. Jego przodkowie w XVI stuleci walczyli w wojnie o Inflanty a ojciec uczestniczył w powstaniu styczniowym w 1863 r. To jedna z najbardziej kontrowersyjnych postaci w korpusie generałów II Rzeczypospolitej. Swoją drogę, życiową związał z wojskiem. Po zdaniu matury i odbyciu służby jednorocznego ochotnika w armii carskiej, wstąpił do Szkoły Junkrów w Rewlu. Następnie służył w 136. Taganarogskim Pułku Piechoty. Walczył w wojnie rosyjsko-japońskiej (1904-1905). W czasie I wojny światowej po zgodzie władz rosyjskich na tworzenie polskich formacji wojskowych był współorganizatorem Brygady Strzelców Polskich, walczył w szeregach Dywizji Strzelców Polskich i I Korpusie Polskim. W końcowym okresie wojny organizował 4. Dywizję Strzelców Polskich (formalnie podlegała Armii Polskiej we Francji i gen. Józefowi Hallerowi), z którą przez Odessę i Besarabię dotarł do Polski. Walczył z wojskami Zachodnioukraińskiej Republiki Ludowej, m. in. o Stanisławów. Następnie na 
czele 10. DP na Froncie Północnym uczestniczył oraz w walkach pod Radzyminem ( w okresie Bitwy Warszawskiej). Po wojnie na czele 1. Dywizji Litewsko-Białoruskiej zajął Wilno i doprowadził do powstania Litwy Środkowej. „Bunt Żeligowskiego" skutkował przyłączeniem tego obszaru do Polski. W Wojsku Polskim pełnił funkcje dowódcy Inspektoratu Armii nr 2 w Warszawie i ministra Spraw Wojskowych. Ze stanowiska odszedł przed zamachem majowym w 1926 r. Generał Żeligowski traktował Piłsudskiego z wielkim szacunkiem. Jak sam napisał we wspomnieniach: „Jako żołnierz nigdy nie mogłem zrozumieć tej zaciętości z jaką niektóre stronnictwa zwalczały Marszałka. Nie służyłem w Legionach i nie byłem Piłsudczykiem (...) Nigdy nie ulegało najmniejszej wątpliwości, że kieruje się tylko interesami Polski ..." ${ }^{\prime 6}$. Po zamachu majowym stanął na czele Komisji Likwidacyjnej powołanej w celu wyjaśnienia okoliczności i przebiegu wypadków majowych w 1926 r. Był również Inspektorem Armii w Generalnym Inspektoracie Sił Zbrojnych. W dniu 31 sierpnia 1927 r. przeszedł w stan spoczynku.

W 1928 r. został prezesem Kapituły Orderu Polonia Restituta oraz członkiem Trybunału Stanu. W 1935 r. wybrany posłem do Sejmu IV kadencji z listy Bezpartyjnego Bloku Współpracy z Rządem - przewodniczył Komisji Wojskowej Sejmu, a następnie Sejmu V kadencji z listy bezpartyjnej. Generał Żeligowski znalazł się w opozycji wobec Obozu Zjednoczenia Narodowego. W okresie II wojny światowej na emigracji we Francji i wielkiej Brytanii, był członkiem Rady Narodowej RP, przewodniczącym jej Komisji Wojskowej oraz Kanclerzem Kapituły Orderu Virtuti Militari Zwolennik słowianofilstwa w okresie powojennym opowiadał się za współpracą z ZSRS. Zmarł w Londynie w 1947 r. Spoczywa na Cmentarzu Wojskowym na Powązkach w Warszawie.

68 Pamiętnik generała broni Lucjana Żeligowskiego...,s. 79 


\section{BIBLIOGRAFIA}

\section{I. ŹRÓDEA ARCHIWALNE:}

Archiwum Akt Nowych w Warszawie

Zespót gen. Lucjana Żeligowskiego 1889-1939, 1944-1947 - sygn.105.

Archiwum Instytutu Józefa Piłsudskiego Ameryce

Adiutantura Generalna Naczelnego Wodza, sygn.701/2.

\section{Centralne Archiwum Wojskowe w Warszawie}

Kolekcja generałów i wielkich osobistości. Akta gen. Lucjana Żeligowskiego, mf. sygn. I.480. 295.

\section{II. ŹRÓDEA PISANE:}

„Dziennik Personalny” z 1920, nr 18, nr 38; z 1921, z 1922, nr 3; z 1922, nr 19, nr 43, z .1923, nr 4; z 1925, nr 129; z 1926, nr 20, nr 44.

„Monitor Polski”, 2007, nr 85, poz.885.

„Rocznik Oficerski” Warszawa 1923; 1924; 1928; 1932.

Cieślikowski Z., Materiały źródłowe do przewrotu majowego, Warszawa 2002.

Rybka R., Stefan K., Awanse oficerskie w Wojsku Polskim w latach 1935-1939, Kraków 2003.

Rybka R., Stefan K., Rocznik oficerski 1939 : stan na dzień 23 marca 1939, Kraków 2006.

\section{ENCYKLOPEDIE I SŁOWNIKI}

Bielski M., Generałowie Odrodzonej Rzeczypospolitej, t. 1-2, Toruń 1995, 1998.

Cieślewicz M., Generałowie polscy w opinii J. Piłsudskiego, „Wojskowy Przegląd Historyczny" 1966, nr 1.

Czuma S., Wójcik W., Generałowie w stalowych mundurach, Warszawa 2003.

Dziennik Tymczasowej Komisji Rządzącej. Litwa Środkowa, Wilno dnia 28 listopada 1920, Nr 4.

Garlicki A., Stawecki P., Przewrót wojskowy w Polsce 1926 r. Wybór dokumentów, cz. I, „Wojskowy Przegląd Historyczny” 1977, nr 2.

Herby rycerstwa polskiego. Przez Bartosza Paprockiego zebrane i wydane w r. p. 1584, Kraków 1858.

Kadry morskie Rzeczypospolitej, t. 2: Polska Marynarka Wojenna, cz. I: Korpus oficerów 1918-1947, pod red. J.K. Stawickiego, Gdynia 1996. 
Kosk H.P., Generalicja polska. Popularny słownik biograficzny, t. 1-2, Pruszków 1998, 2001.

Kryska-Karski T., Żurakowski S., Generałowie Polski Niepodległej, Londyn 1976; wyd. II (uzupełnione i poprawione), Warszawa 1991.

Machaliński Z. , Admirałowie polscy 1919-1950, Warszawa 1993.

Polak B. (red.), Kawalerowie Virituti militari 1792-1945, t. II (1914-1921), cz. 2.

Ruszkowski W. , Kofman J. (red.), Słownik biograficzny Europy Środkowo-Wschodniej XX w., Warszawa 2004.

Sejm Wileński 1922. Przebieg posiedzeń według sprawozdań stenograficznych $w$ opracowaniu kancelarii sejmowej, Wilno 1922, X posiedzenie Sejmu z 20 lutego 1922, s. X/1-22.

Spisok kapitanam armejskoj pehoty po staršinstvu. Sostavlen na 01.11.1913, St. Petersburg 1914.

Spisok polkovnikam po staršinstvu. Sostavlen po 01.08.1916, Piotrogród 1916.

Stawecki P., Słownik biograficzny generałów Wojska Polskiego 1918-1939, Warszawa 1994.

Suchcitz A., Generałowie wojny polsko-sowieckiej 1919-1920. Mały słownik biograficzny, Białystok 1993.

Umowa między Rzecząospolitą Polska i Rzecząospolitą Litewska w sprawie ustanowienia tymczasowego modus vivendi aż do ostatecznego uregulowania stosunków między oboma państwami podpisana w Suwałkach, dnia 7 go października 1920, [w:] League of Nations Treaty Series, 1922, vol. VIII, nr 221.

\section{PAMIĘTNIKI I WSPOMNIENIA}

Dowbór - Muśnicki J., Wspomnienia, Warszawa 2003.

Haller S., Wypadki warszawskie od 12 maja do 15 maja 1926, Kraków 1926.

Pamiętniki generała broni Lucjana Żeligowskiego. Wstęp i oprac. D. Fabisz, Warszawa 2014.

Romeyko M., Przed i po maju, Warszawa 1967.

Wrzos K., Piłsudski i piłsudczycy, Warszawa 1936.

Żeligowski L., Przewrót majowy, [w:] Warszawa w II Rzeczypospolitej 1918-1939, red.

M. Drozdowski, E. Borecka, H. Janowska, Warszawa 1970, z. 2.

Żeligowski L., Wojna w roku 1920. Wspomnienia i rozważania, Warszawa 1930.

Żeligowski L., O ideę słowiańską. London 1941.

L. Żeligowski, Zajęcie Wilna w roku 1920, komentarz i wyd. T. Stańczyk, „Rzeczpospolita", 1992, nr 57.

Żeligowski L., Zapomniane prawdy. London 1941.

\section{MONOGRAFIE I OPRACOWANIA}

Bagińskiego H., Wojsko Polskie na Wschodzie 1914-1920, Warszawa 1921

Bazylow L., Historia powszechna 1798-1918, Warszawa 1981.

Bazylow L., Wieczorkiewicz P.P., Historia Rosji, Wrocław-Warszawa, 2005. 


\section{A. WOJTASZAK $\square$ GeNeRA£ BRONI LUCJAN ŻELIGOWSKI $(1865-1947) \ldots$}

Fabisz D., Generał Lucjan Żeligowski 1865-1947. Działalność wojskowa i polityczna, Warszawa 2007.

Gumowska G., Opowieść o gen. broni Lucjanie Żeligowskim, Bydgoszcz 1994, cz. 1. Lata 1865-1920, Bydgoszcz 1994.

Jaxa-Ronkier B., Dzierżyński. „Czerwony kat”, Warszawa 1933.

Kaźniewski T., Wojsko Polskie w Rosji w czasie rewolucji 1917-1918, Warszawa 1935.

Mackiewicz S. (Cat), Lata nadziei 17 września 1939 r. - 5 lipca 1945 r., Warszawa 1990.

Russko-Âponskaâ vojna 1904-1905 gg., T. I - IX. ( Русско-Японская война 1904-1905 22. T. I - IX.), Petersburg 1910.

Stawecki P., Generałowie polscy. Zarys portretu zbiorowego 1776-1945, Warszawa 2010. Wojtaszak A., Generalicja Wojska Polskiego 1918-1926, Szczecin-Warszawa 2012.

Wojtaszak A.,Generalicja Wojska Polskiego 1935-1939. (Analiza grupy funkcjonalno-decyzyjnej), Szczecin 2018.

Wrzosek M., Polski czyn zbrojny podczas I wojny światowej 1914-1918, Warszawa 1990. Wyszczelski L, Ministerstwo Spraw Wojskowych (1918-1939), Warszawa 2010.

\section{ARTYKUEY NAUKOWE}

Fabisz D., Generał Lucjan Żeligowski w walce o Polskę i jej granice w latach 1914-1921, [w:] Listopad 1918 z perspektywy osiemdziesięciolecia, red. Cz. Osękowski, Zielona Góra 2000.

Galas K., Generał broni Lucjan Żeligowski i jego zasługi dla niepodległości Rzeczypospolitej Polskiej, „Niepodległość i Pamięć», 2009 nr 29.

Kicman W., Jeszcze w sprawie gen. broni L. Żeligowskiego, «Wojskowy Przegląd Historyczny», 1988, nr 2.

Mackiewicz (Cat) S., Generał Żeligowski, „Słowo”, 1930, nr 232

Marczyk W., Generał broni Lucjan Żeligowski, „Wojskowy Przegląd Historyczny” 1987, nr 4;

Suleja W., Zamach majowy, [w:] Polski wiek XX. Dwudziestolecie, pod red. K.Persaka i P. Machcewicza, Warszawa 2009.

Waligóra B., Zajęcie Wilna przez gen. Żeligowskiego, „Bellona”, T.36, 1930.

W.P. Akcja zbrojna i dyplomatyczna o Wilno, w: Wilno wyzwolone. Jednodniówka na zjazd byłych uczestników walk o Wilno w dniach 10-11 XI.1930 r. Wilno 1930.

Woszczyński B., Wypadki majowe 1926 roku w liczbach, „Najnowsze Dzieje Polski. Materiały i Studia z okresu 1914-1939”, 1966, t. X.

VI. Materiały internetowe:

Informacje o rodzie Żeligowskich, [w: ] http://www.oszmianszczyzna.pl/genealogia_zeligowski.html\#general (dostęp: 2.06.2019).

Russkaâ armiâ v Velikoj vojne, (Русская армия в Великой войне, [w:] http://www. grwar.ru/ persons/persons.html?id=1817, data dostępu: 2.06.2019). 